\title{
Intraspecific variation in reproductive and somatic growth cycles of bay scallops Argopecten irradians
}

\author{
V. M. Bricelj, J. Epp \& R. E. Malouf \\ Marine Sciences Research Center, State University of New York at Stony Brook, New York 11794, USA
}

\begin{abstract}
The extent of intraspecific variability in fecundity, and reproductive and somatic (adductor muscle) growth cycles is examined among 4 adjacent, New York populations of bay scallops Argopecten irradians Lamarck. Mid-latitude populations are compared to previously studied populations at the northern and southern extremes of the species' geographical distribution along the east coast of the USA. Major spawning occurred in early June, followed by secondary spawning in July and early August. Spawning intensity (percent of gonad evacuation during first spawning) ranged from $62 \%$ at the shallower site $(1 \mathrm{~m})$ to $22 \%$ at the deepest site $(3.5 \mathrm{~m})$. This difference is temperature related. Mean fecundity (annual egg production) - not previously reported for this species - was determined from weight loss on spawning. It ranged from 12.6 to $18.6 \times 10^{6}$ per 1 st year scallop. Individuals that survived to a 2 nd spawning averaged significantly lower gonad output than expected from the linear regression of log gonad weight on log shell height in younger scallops. Greatest differences in mean shell height, adductor muscle weight in the fall, and fecundity were observed between 2 adjacent sites only $1.5 \mathrm{~km}$ apart. Results of this study suggest that scallops are food limited within shallow, enclosed bays, where circulation is more restricted. Size-specific fecundity of midlatitude New York bay scallops is 7 times greater than that of Florida scallops, at the southern limit of their distribution. The ratio of reproductive output to somatic tissue weight of $A$. $i$. irradians is also 2 to 8 times greater than the maximum ratio attained by iteroparous, longer-lived pectinids. A persistent picoplanktonic bloom in summer 1985 caused starvation and $76 \%$ reduction in muscle weight of adults relative to 1984 . Following waning of the bloom, survivors displayed remarkable resilience, reflected in a 3 -fold increase in mean muscle weight during September.
\end{abstract}

\section{INTRODUCTION}

The bay scallop is a semelparous, functional hermaphrodite occurring in shallow $(<12 \mathrm{~m})$ protected embayments on the east coast of the United States. Its life span varies from 1 to $2 \frac{1}{2} \mathrm{yr}_{\text {; }}$ thus, few individuals survive to a second spawning (Gutsell 1930, Barber \& Blake 1981). Mass senescent mortality of bay scallops in New York waters occurs during their second winter of life (unpubl. data). Argopecten irradians Lamarck is distributed from Cape Cod, Massachusetts, to South Carolina along the Atlantic coast, and from Tampa Bay, Florida to eastern Texas along the Gulf Coast (Clarke 1965). Distinction between a northem subspecies, A. i. irradians, from Massachusetts to Long Island, New York, and a southern subspecies, $A$. i. concentricus, is based on shell morphometrics (Clarke 1965) and has not been substantiated by examining genetic differentiation.

Significant differences in growth and reproductive cycles have been reported for this species along its geographic range (Sastry 1970, 1979, Barber \& Blake 1983). In general, reproductive events occur later in the year and at higher water temperatures at more southern latitudes. In Massachusetts $\left(42^{\circ} \mathrm{N}\right.$ latitude) gonad growth is initiated in April when temperatures are about $10^{\circ} \mathrm{C}$, the gonad index peaks in July/August and spawning occurs during the summer (Aug/Sep) (Sastry $1970)$. In North Carolina $\left(35^{\circ} \mathrm{N}\right)$ gonad growth commences in June at temperatures above $20^{\circ} \mathrm{C}$. Gonad growth peaks in September and spawning takes place in the fall (October) (Sastry 1970, 1979). In Florida $\left(28^{\circ} \mathrm{N}\right)$ gonad index peaks in the fall and spawning commences in October (Barber \& Blake 1983). The maximum gonad condition and oocyte diameter are found to decrease with decreasing latitude (Barber \& Blake 1983). This trend is accompanied by a latitudinal shift in the source of energy reserves mobilized for reproduction. As illustrated for east coast Mytilus edulis populations, habitat-specific differences in food 
availability may, however, override the overall effect of latitude in determining the timing of the reproductive cycle of bivalves (Newell et al. 1982). While the bay scallop's reproductive pattern is well documented at its northern and southern distributional limits, little is known about mid-latitude, New York populations $\left(41^{\circ} \mathrm{N}\right)$.

Bayne et al. (1983) found similarities in egg size, reproductive effort and the relation between fecundity and body size among mussel Mytilus edulis populations from different habitats along the British coast. In contrast, other properties of a species' reproductive strategy such as fecundity (Bayne et al. 1983, MacDonald \& Thompson 1985), and the timing of gametogenesis and spawning (Newell et al. 1982), are often highly variable between sites or depths within a relatively small geographical region. The main objective of the present paper is to examine the extent of intraspecific variability in reproductive patterns among neighboring bay scallop populations in eastern Long Island, New York, USA. These mid-latitude populations are compared to those at their northern and southern distributional limits along the east coast of the USA, where most of the data published to date has been obtained. Specifically, this study reports on the timing, intensity and duration of spawning activity, degree of synchrony among individuals, fecundity and the relationship between gamete production and age as well as size. Fecundity estimates have not been previously reported for this species.

In bivalve molluscs the reproductive cycle is generally closely linked to a cycle of energy storage and utilization (Sastry 1979). The adductor muscle is the main energy storage site used by bay scallops for gonadal development (Barber \& Blake 1981, Bricelj unpubl. data), and is the only marketable portion of scallops in the USA. A second objective of this study is to relate the growth cycle of the adductor muscle to the reproductive cycle. Finally, this paper documents the effects on growth of adult scallops of an unusual microalgal bloom, which persisted throughout the summer of 1985 in Long Island's embayments and is believed to have caused massive recruitment failure of the 1985 year class.

\section{METHODS}

Bay scallops Argopecten irradians for this study were sampled from 3 embayments in Long Island, New York, USA: Sag Harbor (mean depth $=1 \mathrm{~m}$ ), Mashomack Point $(2 \mathrm{~m})$ and Barcelona Neck $(3.5 \mathrm{~m})$ in Northwest Harbor, and Three Mile Harbor (2 m) (Fig. 1). Scaliops are commercialiy harvested at ali iocations except the Sag Harbor site, where populations are thus least likely to be disturbed following the opening of the scallop season. Legal harvesting in New York State waters extends from September to March. Preliminary surveys of the Peconic estuary were conducted in an attempt to locate a scallop population in deeper waters, but scallops were scarce at depths greater than about 4 to $5 \mathrm{~m}$. The sites selected are thus representative in terms of depth, substrate and hydrodynamic conditions of the range of habitats in which scallops occur on Long Island. Water exchange is relatively reduced within Three Mile Harbor and particularly within Sag Harbor, where current speed is further reduced by dense eelgrass cover. Northwest Harbor is directly connected with Gardiner's Bay and the open ocean, and thus exposed to a stronger tidal flow, particularly at Mashomack Point. Surface current vel-

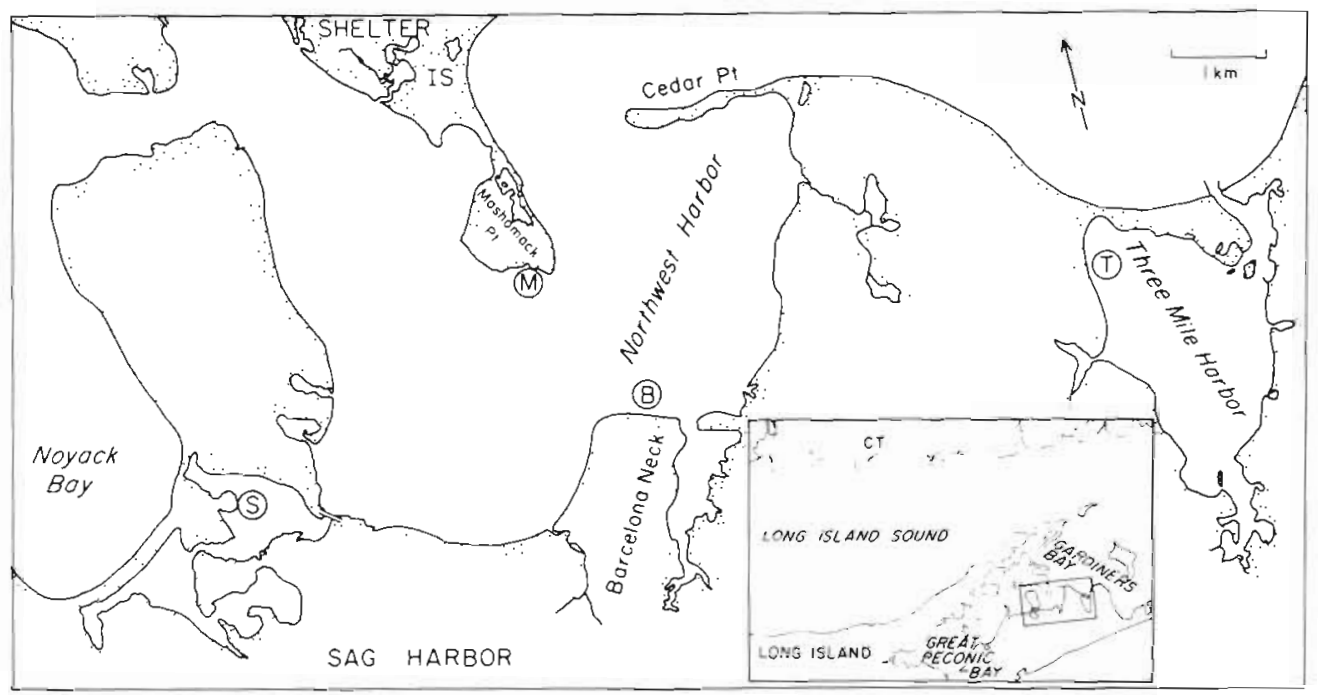

Fig. 1. Location of scallop collection sites in eastern Long Island, New York, USA. S: Sag Harbor; B: Barcelona; M: Mashomack; T: Three Mile Harbor 
ocities at Mashomack during flood and ebb tide can attain $90 \mathrm{~cm} \mathrm{~s}^{-1}$ (Hardy 1976) and are approximately 3 times those near Barcelona Point (Eckman in press).

About 60 scallops were collected at each site at approximately weekly or fortnightly intervals between May and September of 1984 . They were obtained with a manually operated dredge lined with a $1 \mathrm{~cm}$ wire mesh which allowed capture of sublegal scallops. The dredge was normally towed parallel to the shore to minimize sampling at variable depths. Scallops were hand-collected by diving at Sag Harbor, where the soft substrate and heavy eelgrass cover prevented efficient operation of the dredge. Only adult scallops were collected for this study, i. e. primarily individuals of the 1983 year class. No attempt was made to sample the 1984 recruits, but intense sampling was carried out to locate any surviving second year scallops (1982 cohort). These were distinguished by the presence of the annual growth ring. Depth, surface water temperature (measured with a hand-held thermometer) and salinity (measured to the nearest ppt using a refractometer) were recorded at each station and sampling date. The water column is vertically homogeneous due to intense tidal mixing: the difference between surface and bottom temperatures never exceeded $0.5 \mathrm{C}^{\circ}$.

Scallops were frozen, and shell dimensions, namely height (maximum dimension from the umbo to the ventral margin), and thickness (inflation) of intact paired valves were determined with vernier calipers to the nearest $0.1 \mathrm{~mm}$. Adductor muscles and gonads (including both male and female sections) of a minimum of about 30 scallops were dissected to obtain dry weights (after oven-drying at $85^{\circ} \mathrm{C}$ for $48 \mathrm{~h}$ ) and ash-free dry weights (AFDW) (following $24 \mathrm{~h}$ combustion at $470^{\circ} \mathrm{C}$ ). Ash-free dry weights were used in order to eliminate the contribution of sediments in the gut, since the intestine in scallops coils through the gonad. The presence of 'mud blisters' caused by infestation of the polychaete Polydora sp., was recorded at most stations.

Linear regressions of gonad AFDW and adductor muscle AFDW versus shell height following logarithmic $\left(\log _{10}\right)$ transformation of variates were calculated for each site and sampling date. Only younger scallops, of the 1983 cohort, were included in the regressions. For regression analysis, random samples of first year scallops were enriched with individuals at the extremes of the size-frequency distribution but belonging to the same cohort, in order to examine as broad a range of observations as possible. Geometric mean (GM) or functional regressions were used following recommendations made by Ricker (1973). Selection of the most appropriate method of Model II regression is under continued debate (Sokal \& Rholf 1981). GM regressions are appropriate when both variables are subject to natural variability, and provide unbiased estimates of the slope and intercept when comparing populations of different size ranges and absolute sizes (Ricker 1973). The gonad and adductor muscle condition were determined from the body component weight of a scallop of standard shell height, e. g. $45 \mathrm{~mm}$, in order to eliminate the confounding effect of body size. This parameter replaced the traditionally used body component index [(weight of a body component/total tissue weight) $\times 100$ ], which in this study was calculated for a single site, Three Mile Harbor, to allow comparison with earlier studies.

Fecundity was determined by the indirect gravimetric method (Bayne et al. 1983, Thompson 1984) from the difference in gonad weight of a scallop of average height (calculated from the appropriate regression equation) just prior to spawning and after spawning, i. e. as the 'weight loss on spawning'. Male and female sections of the gonads of 20 scallops collected from Sag Harbor at the peak of their gonad condition were dissected and weighed separately, in order to determine the relative allocation to male versus female reproductive tissues. Reproductive condition from histological examination of gonads fixed in Bouin's solution, was assessed for 10 individuals collected from Barcelona and Sag Harbor on August 8.

Differences in mean shell height and muscle weight among sites were assessed using single classification ANOVA, followed by multiple comparisons among pairs of means. The T' and GT2 methods (Sokal \& Rholf 1981) were used for nearly equal and unequal sample sizes, respectively.

At the end of the sampling period, $10 \mathrm{~cm}$ deep, $2.8 \mathrm{~cm}$ wide sediment cores were obtained with $50 \mathrm{ml}$ plastic syringes with cut out ends. These were frozen for subsequent grain-size analysis. A crude measure of the areal density of scallop populations was obtained from 4 replicate underwater transects at each site: all individuals within an arm's length on either side were collected by a diver swimming along a marked $10 \mathrm{~m}$ nylon line stretched along the bottom.

About 20 scallops were periodically transported live to the Flax Pond Laboratory where they were maintained in flowing seawater at $17^{\circ} \mathrm{C}$. Scallops were induced to spawn by placing them individually in dishes and raising the temperature to about $26^{\circ} \mathrm{C}$. The proportion that spawned male and/or female gametes within $4 \mathrm{~h}$ of stimulation was recorded for Sag Harbor scallops. Spawned, unfertilized oocytes from individual scallops were collected on a $25 \mu \mathrm{m}$ mesh nitex screen to remove debris, and resuspended in filtered seawater and fixed with Lugol's solution. Oocyte sizefrequency distributions were obtained with an electronic particle counter (Particle Data Electrozone Celloscopel fitted with a $380 \mu \mathrm{m}$ orifice. Fertilization of 
Table 1. Characteristics of the study sites, Long Island, New York, USA

\begin{tabular}{|c|c|c|c|c|c|}
\hline \multirow[t]{2}{*}{ Site } & \multicolumn{2}{|c|}{ Sediment characteristics } & \multirow[t]{2}{*}{ Dominant vegetation } & \multirow{2}{*}{$\begin{array}{l}\text { Salinity } \bar{X}(p p t) \\
\text { (Range) }\end{array}$} & \multirow{2}{*}{$\begin{array}{c}\text { Density } \\
\left(\text { scallops } \mathrm{m}^{-2} \text { ) }\right.\end{array}$} \\
\hline & $\begin{array}{c}\% \text { Silt }+ \text { clay } \\
\bar{X}( \pm S D)\end{array}$ & $\begin{array}{c}\% \text { Organic matter } \\
\bar{X}( \pm S D)\end{array}$ & & & \\
\hline Sag Harbor & $\begin{array}{l}{ }^{\star} 68.0( \pm 2.2) \\
{ }^{\mathrm{b}} 14.9( \pm 6.7)\end{array}$ & $\begin{array}{l}7.8( \pm 0.5) \\
2.3( \pm 0.9)\end{array}$ & $\begin{array}{l}\text { Zostera marina }+ \\
\text { Gracilaria tikvahiae } \\
\text { (dense) }\end{array}$ & $\begin{array}{c}25 \\
(24-27)\end{array}$ & 2 \\
\hline Barcelona & $5.1( \pm 0.8)$ & $1.0( \pm 0.2)$ & Unvegetated & $\begin{array}{c}28 \\
(26-29)\end{array}$ & $\begin{array}{l}2.4 \\
0.3-4.4\end{array}$ \\
\hline Mashomack & $4.0( \pm 1.4)$ & $0.9( \pm 0.2)$ & $\begin{array}{l}\text { Codium fragile }+ \\
\text { Zostera marina (moderate) }\end{array}$ & $\begin{array}{c}28 \\
(26-29)\end{array}$ & 0.2 \\
\hline Three Mile Harbor & Sandy & Low & Unvegetated & $\begin{array}{c}27 \\
(25-29)\end{array}$ & - \\
\hline $\begin{array}{l}{ }^{\circledR} \text { Eelgrass bed } \\
{ }^{b} \text { Open patch }\end{array}$ & & & & & \\
\hline
\end{tabular}

oocytes was avoided by collecting oocytes exclusively from scallops which spawned first as females and before they released sperm. To confirm this, oocytes were examined under the microscope; less than $5 \%$ showed polar bodies or signs of cleavage. Egg weights were measured after rinsing on tared, Whatman GF/C glass-fiber filters with isotonic ammonium formate solution and oven-drying at $85^{\circ} \mathrm{C}$, and used to convert fecundities in terms of AFDW to egg numbers.

Sag Harbor scallops were sampled again between July and October 1985 to determine the effect of that summer's unusually persistent algal bloom on the adult population. Water samples were preserved with Lugol's solution and the concentration of the bloom species was determined microscopically using a haemocytometer.

\section{RESULTS}

Table 1 summarizes the main characteristics of the study sites. At the shallow Sag Harbor station scallops were found on a substrate of fine-grained surface sediments compacted by dense eelgrass Zostera marina and mats of the red seaweed Gracilaria sp. Silt-clay content of surface sediments in vegetated areas greatly exceeded that of interspersed patches of bare substrate. Salinities were significantly lower at this site than at other locations.

Barcelona Neck, the deepest station, lies within Northwest Harbor, an area heavily exploited commercially because of its high scallop densities and consistently reliable sets. Scallops had a patchy distribution, and occurred on sandy, unvegetated bottom; Zostera

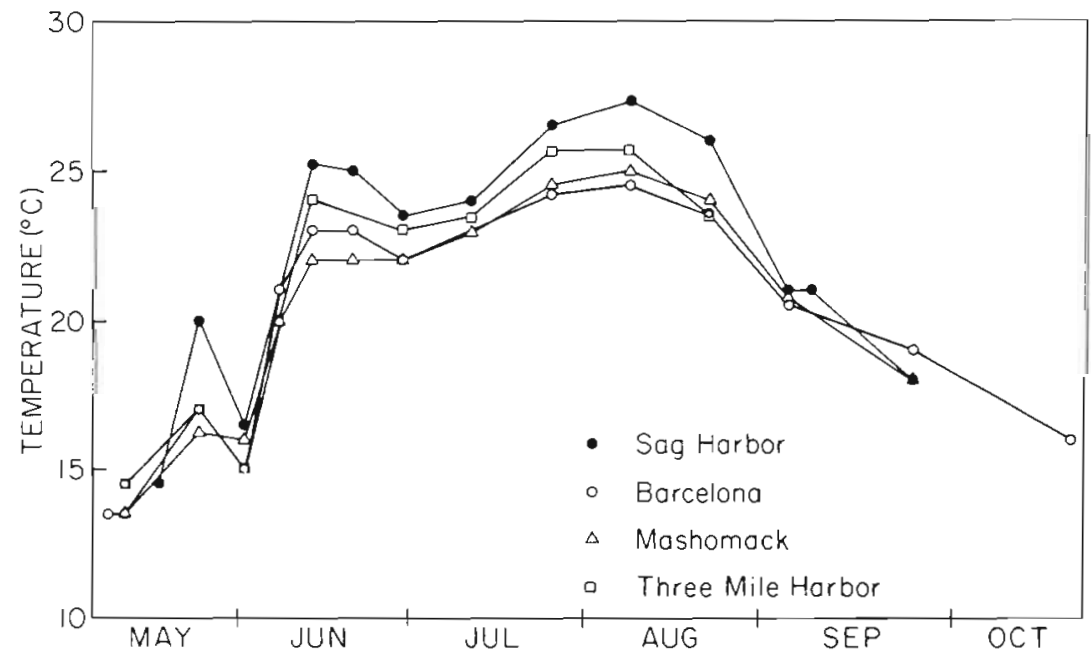

Fig. 2. Seasonal water temperature cycle at the 4 sampling sites 
marina which is abundant closer to shore, becomes light limited at the depth sampled. The Mashomack Point site, which is exposed to stronger tidal flow, lies directly across from Barcelona, separated by a 6 to $8 \mathrm{~m}$ deep channel.

Prevalence of commensal pea crabs Pinnotheres sp., which can adversely affect tissue growth of scallops (Kruczynski 1972), averaged only $1.4 \%$ (range: 0 to $9.4 \%$ ) at any given sampling date in the populations studied. Infestation by the boring spionid polychaete Polydora sp., which has been associated with unusually high mortalities of bay scallops in Massachusetts (Turner \& Hanks 1959), and low growth rates of scallops in Japan (Mori et al. 1985), was more prevalent. The percentage of scallops with 'mud blisters' increased from 2 to $28 \%$ from May through August at Mashomack, 0 to $23 \%$ at Barcelona, and 0 to $81 \%$ at Three Mile Harbor, where the highest incidence was recorded.

\section{Timing and duration of spawning}

Peak gonadal condition was attained by June 1 at the 2 Northwest Harbor sites, and at Three Mile Harbor when water temperatures were 15 to $16^{\circ} \mathrm{C}$ (Fig. 2). At Sag Harbor, scallops were ready to spawn 2 wk earlier (May 17; water temperature $=14.5^{\circ} \mathrm{C}$ ) than at the other sites. This can be correlated with the relatively higher temperatures and more rapid rise in water temperature experienced at this shallow site.

Analysis of changes in gonadal condition at weekly intervals allowed fairly precise timing of spawning events in this study (Fig. 3). Major spawning was initiated at all locations during the first week of June, coinciding with a rapid increase in water temperature from 15 to $16^{\circ} \mathrm{C}$ to 20 to $21{ }^{\circ} \mathrm{C}$. Sag Harbor again differed from other sites in that spawning was initiated earlier (in the 3rd or 4 th week of May), coinciding with a sharp increase in temperature from 14.5 to $20^{\circ} \mathrm{C}$ at this time. This is consistent with reports by Belding (1931) and Taylor \& Capuzzo (1983) indicating that scallops in Massachussets spawn when water temperature exceeds $18^{\circ} \mathrm{C}$, before the summer maximum is attained.

Although the main spawning event took place during early June, secondary spawning occurred throughout July and early August at all stations. The percentage of gonad evacuation taking place during
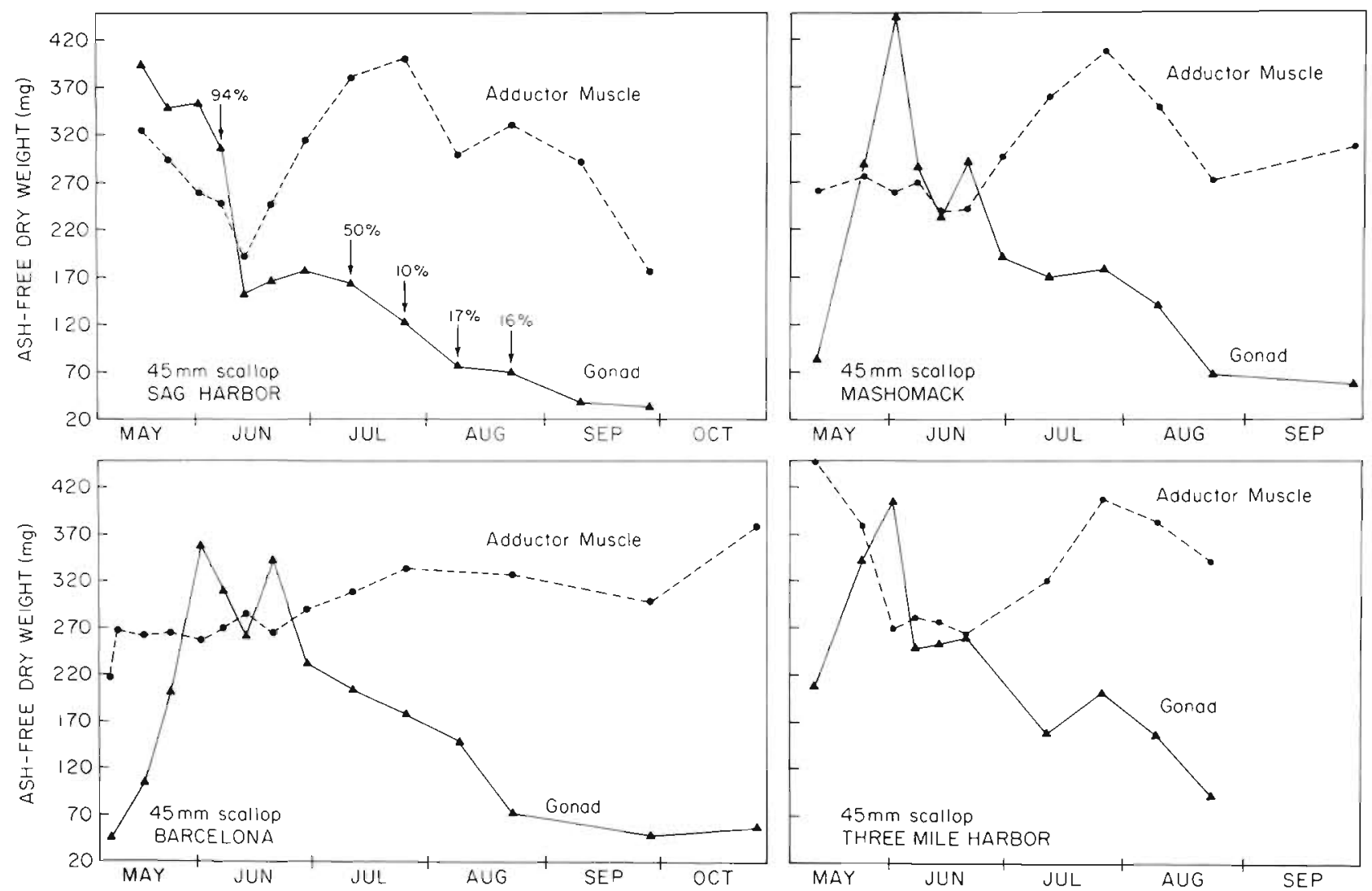

Fig. 3. Argopecten irradians. Ash-free dry tissue weight (gonad and adductor muscle) for a standard sized $45 \mathrm{~mm}$ scallop at the 4 study sites (calculated from regression equations in Tables $3 \& 4$ ). Arrows: percentage of individuals that responded to laboratory spawning induction 
the initial spawning event varied, however, among locations. Maximum gamete output at first spawning ( $62 \%$ of the total) was recorded at Sag Harbor, the shallower site, and lowest output (22\%) was observed at Barcelona, the deepest study site (Table 2). Intermediate gonadal evacuation ( 34 to $46 \%$ ) during initial spawning occurred at the other 2 sites, intermediate in depth range. These differences appear to be temperature related. Sag Harbor experienced early spring warming, with temperatures rising sharply to $20^{\circ} \mathrm{C}$ during late May, while they remained below $17^{\circ} \mathrm{C}$ until June at the other sites. Although absolute temperatures are comparable at Mashomack and Barcelona, greater daily temperature fluctuations are expected with decreasing depth.

Greatest differences (of up to $39 \%$ ) in mean annual fecundity were observed between the 2 adjacent sites, Barcelona and Mashomack (Table 2). These differences can be partially attributed to the significantly larger mean size of scallops at Mashomack (ANOVA and GT2-test, $p<0.05$ ), but also to the fact that at this site scallops attained a higher gonadal condition before spawning was triggered by the increase in ambient temperatures in early June (Table 2, Fig. 3).

Tables 3 \& 4 show regression parameters for gonad and adductor muscle weight, respectively, on shell height. The coefficient of determination $\left(\mathrm{r}^{2}\right)$ is generally higher for muscle-height regressions than for gonad-height regressions. Gonadal weight for a given shell size was thus more variable than muscle weight.
Before spawning, between 53 and $91 \%$ of the variation in gonad weight is attributable to variation in shell height. Lower $r^{2}$ values are obtained after peak spawning, reflecting asynchrony in spawning activity among individuals.

The gradual decline in gonadal condition throughout July and August is attributed to secondary, protracted spawning activity, rather than resorption of gametes. Two lines of evidence support this statement. A significant fraction (50\%) of Sag Harbor scallops spawned in the laboratory in response to thermal stimulation in early July. The percentage of individuals successfully induced to spawn is indicated by arrows in Fig. 3. Additionally, histological analysis of gonads from Barcelona and Sag Harbor scallops, collected on August 8, revealed individuals both in partially spawned and spent conditions. No signs of oocyte resorption and cytolysis were apparent at that time. Oocytes spawned in the laboratory exhibited a narrow, unimodal size-frequency distribution (mean diameter $=54.2 \mu \mathrm{m}$, $\mathrm{SD}=1.6$ ). Prior to spawning, the female section contributed $46.0 \%(S D=4.70 ; n=20)$ of the total gonadal ash-free dry weight. Thus, although spermatogenesis proceeds at a faster rate than oogenesis in Argopecten irradians (Sastry 1966, 1979), equal allocation is observed between male and female reproductive tissues before spawning. This is consistent with theoretical arguments put forward by Williams (1966) for gamete allocation in a functional hermaphrodite.

Table 2. Argopecten irradians. Reproductive output, shell height, and adductor muscle weight and condition in the fall of 1984 at the study sites

\begin{tabular}{|c|c|c|c|c|}
\hline Parameter & Sag Harbor & Three Mile Harbor & Barcelona & Mashomack \\
\hline \multicolumn{5}{|l|}{ Mean gamete output (mg AFDW) } \\
\hline First spawning & $\begin{array}{c}269 \\
(62 \%)\end{array}$ & $\begin{array}{c}154 \\
(34 \%)\end{array}$ & $\begin{array}{c}73 \\
(22 \%)\end{array}$ & $\begin{array}{c}232 \\
(46 \%)\end{array}$ \\
\hline Secondary spawning & 167 & 300 & 263 & 270 \\
\hline Total & 436 & 454 & 337 & 501 \\
\hline Oocytes spawned scallop ${ }^{-1}\left(\times 10^{6}\right)^{d}$ & 16.2 & 16.9 & 12.6 & 18.6 \\
\hline Gonad condition ${ }^{b}$ & 393 & 406 & 357 & 443 \\
\hline Shell height $(\mathrm{mm})^{c} \bar{X} \pm \mathrm{SD}$ & $\begin{array}{c}47.7 \\
( \pm 4.05)\end{array}$ & $\begin{array}{c}43.7 \\
( \pm 4.19)\end{array}$ & $\begin{array}{c}43.4 \\
( \pm 2.85)\end{array}$ & $\begin{array}{c}45.9 \\
( \pm 3.79)\end{array}$ \\
\hline Shell height (mm) $\bar{X} \pm S D$, Sep 27 & $\begin{array}{c}57.3 \\
( \pm 3.30)\end{array}$ & - & $\begin{array}{c}53.1 \\
( \pm 3.63)\end{array}$ & $\begin{array}{c}55.6 \\
( \pm 4.35)\end{array}$ \\
\hline Adductor muscle wt (mg AFDW), Sep 27 & $\begin{array}{c}698.3 \\
( \pm 211.78)\end{array}$ & - & $\begin{array}{c}633.2 \\
( \pm 175.42)\end{array}$ & $\begin{array}{c}831.7 \\
( \pm 249.49)\end{array}$ \\
\hline Adductor muscle condition ${ }^{d}$, Sep 27 & 176 & - & 297 & 313 \\
\hline \multicolumn{5}{|c|}{${ }^{\mathrm{a}}$ Conversion factor $=13.426 \mathrm{mg}$ AFDW per million oocytes } \\
\hline $\begin{array}{l}{ }^{2} \text { Peak gonadal weight (mg AFDW) of a st } \\
\text { Jun } 1 \text { for other sites) } \\
\text { At the time when peak gonadal weight } \\
\text { 'Muscle weight (mg AFDW) of a standar }\end{array}$ & $\begin{array}{l}\text { lard sized, } 45 \\
\text { ttained } \\
\text { zed, } 45 \mathrm{~mm} \mathrm{~s}\end{array}$ & $\begin{array}{l}\text { scallop prior to spaw } \\
\text { op }\end{array}$ & (May 17 for & rbor scallops and \\
\hline
\end{tabular}


Table 3. Argopecten irradians. Regression parameters of gonad ash-free dry weight $(\mathrm{G}, \mathrm{mg})$ on shell height $(\mathrm{H}, \mathrm{mm})$ following the relation: $\log \mathrm{G}=\log \mathrm{a}+\mathrm{b} \log \mathrm{H} . \mathrm{r}^{2}$ : coefficient of determination

\begin{tabular}{|c|c|c|c|c|c|c|c|c|c|c|c|c|c|}
\hline \multirow{2}{*}{\multicolumn{2}{|c|}{$\begin{array}{l}\text { Date } \\
(1984)\end{array}$}} & \multicolumn{4}{|c|}{ Mashomack } & \multicolumn{4}{|c|}{ Sag Harbor } & \multicolumn{4}{|c|}{ Barcelona } \\
\hline & & $\log a$ & $\mathrm{~b}$ & $r^{2}$ & $n$ & $\log a$ & $\mathrm{~b}$ & $r^{2}$ & $\mathrm{n}$ & $\log a$ & $b$ & $r^{2}$ & $n$ \\
\hline \multirow[t]{4}{*}{ May } & 8 & & - & & & & - & & & -3.511 & 3.127 & 0.60 & 32 \\
\hline & 11 & -5.343 & 4.390 & 0.53 & 32 & & - & & & & - & - & \\
\hline & 17 & & - & & & -2.203 & 2.902 & 0.59 & 35 & -3.727 & 3.477 & 0.61 & 32 \\
\hline & 24 & -3.237 & 3.446 & 0.54 & 30 & -2.608 & 3.115 & 0.70 & 39 & -4.323 & 4.008 & 0.70 & 24 \\
\hline \multirow[t]{5}{*}{ Jun } & 1 & -3.244 & 3.563 & 0.56 & 30 & -1.526 & 2.464 & 0.62 & 40 & -3.795 & 3.839 & 0.54 & 32 \\
\hline & 7 & -2.663 & 3.088 & 0.60 & 30 & -4.304 & 4.106 & 0.32 & 68 & -3.292 & 3.497 & 0.68 & 32 \\
\hline & 13 & -2.576 & 2.989 & 0.58 & 30 & -2.828 & 3.031 & 0.39 & 32 & -1.878 & 2.598 & 0.60 & 32 \\
\hline & 20 & -4.613 & 4.280 & 0.34 & 30 & -2.460 & 2.830 & 0.48 & 30 & -2.424 & 2.998 & 0.58 & 28 \\
\hline & 29 & -3.267 & 3.355 & 0.65 & 32 & -1.708 & 2.393 & 0.33 & 30 & -1.813 & 2.527 & 0.75 & 28 \\
\hline \multirow{2}{*}{ Jul } & 11 & -3.730 & 3.606 & 0.47 & 55 & -2.354 & 2.762 & 0.39 & 28 & -2.501 & 2.908 & 0.66 & 32 \\
\hline & 25 & -4.196 & 3.899 & 0.18 & 47 & -3.750 & 3.532 & 0.24 & 46 & -2.177 & 2.676 & 0.53 & 32 \\
\hline \multirow[t]{2}{*}{ Aug } & 8 & -2.745 & 2.957 & 0.50 & 67 & -4.438 & 3.823 & 0.14 & 47 & -2.181 & 2.632 & 0.32 & 56 \\
\hline & 22 & -8.196 & 6.064 & 0.51 & 56 & -3.892 & 3.469 & 0.31 & 55 & -5.744 & 4.596 & 0.24 & 32 \\
\hline \multirow[t]{2}{*}{ Sep } & 9 & & - & & & -4.877 & 3.906 & 0.09 & 27 & & - & & \\
\hline & 27 & -2.550 & 2.607 & 0.74 & 13 & -5.370 & 4.172 & 0.56 & 28 & -3.440 & 3.099 & 0.32 & 44 \\
\hline Oct & 25 & & - & & & & - & & & -3.508 & 3.182 & 0.90 & 55 \\
\hline
\end{tabular}

Table 4. Argopecten irradians. Regression parameters of adductor muscle ash-free dry weight (A, mg) on shell height (H, mm) following the relation: $\log \mathrm{A}=\log \mathrm{a}+\mathrm{b} \log \mathrm{H}$. $\mathrm{r}^{2}$ : coefficient of determination; $\mathrm{n}$ as in Table 3 )

\begin{tabular}{|c|c|c|c|c|c|c|c|c|c|c|}
\hline \multirow{2}{*}{\multicolumn{2}{|c|}{$\begin{array}{c}\text { Date } \\
(1984)\end{array}$}} & \multicolumn{3}{|c|}{ Mashomack } & \multicolumn{3}{|c|}{ Sag Harbor } & \multicolumn{3}{|c|}{ Barcelona } \\
\hline & & $\log a$ & $\mathrm{~b}$ & $r^{2}$ & $\log a$ & b & $r^{2}$ & $\log a$ & $\mathrm{~b}$ & $r^{2}$ \\
\hline \multirow[t]{4}{*}{ May } & 8 & & - & & & - & & -2.865 & 3.146 & 0.76 \\
\hline & 11 & -4.606 & 4.248 & 0.78 & & - & & & - & \\
\hline & 17 & & - & & -2.733 & 3.172 & 0.77 & -2.878 & 3.203 & 0.87 \\
\hline & 24 & -3.642 & 3.682 & 0.86 & -2.527 & 3.022 & 0.80 & -2.841 & 3.184 & 0.78 \\
\hline \multirow[t]{5}{*}{ Jun } & 1 & -3.117 & 3.345 & 0.67 & -2.080 & 2.717 & 0.81 & -2.780 & 3.138 & 0.72 \\
\hline & 7 & -2.846 & 3.194 & 0.73 & -2.446 & 2.928 & 0.64 & -2.603 & 3.044 & 0.64 \\
\hline & 13 & -2.656 & 3.064 & 0.53 & -3.665 & 3.597 & 0.37 & -2.510 & 3.002 & 0.62 \\
\hline & 20 & -2.451 & 2.923 & 0.38 & -2.521 & 2.972 & 0.39 & -1.707 & 2.497 & 0.70 \\
\hline & 29 & -2.060 & 2.735 & 0.47 & -1.945 & 2.687 & 0.35 & -1.827 & 2.593 & 0.71 \\
\hline \multirow[t]{2}{*}{ Jul } & 11 & -4.390 & 4.188 & 0.49 & -2.090 & 2.825 & 0.54 & -2.686 & 3.130 & 0.71 \\
\hline & 25 & -3.416 & 3.647 & 0.41 & -2.713 & 3.216 & 0.40 & -2.912 & 3.288 & 0.55 \\
\hline \multirow[t]{2}{*}{ Aug } & 8 & -5.105 & 4.627 & 0.62 & -4.182 & 4.027 & 0.54 & -3.973 & 3.871 & 0.68 \\
\hline & 22 & -6.563 & 5.449 & 0.10 & -3.455 & 3.614 & 0.78 & -4.294 & 4.118 & 0.65 \\
\hline \multirow[t]{2}{*}{ Sep } & 9 & & - & & -4.244 & 4.058 & 0.26 & & - & \\
\hline & 27 & -4.615 & 4.301 & 0.83 & -6.918 & 5.543 & 0.43 & -4.806 & 4.403 & 0.62 \\
\hline Oct & 25 & & - & & & - & & -3.594 & 3.733 & 0.89 \\
\hline
\end{tabular}

\section{Reproductive output in relation to size and age}

Only 17 2nd year scallops (1982 year class) were collected throughout the entire sampling area and sampling period. None were found at Barcelona, where the populations are heavily exploited. The 1982 cohort (mean shell height $=63.2 \mathrm{~mm}, \mathrm{SD}=2.51$ ) was present until the first week of June, suggesting that the maximum life span of scallops is about 23 mo in Long Island waters (assuming July recruitment of set [Hickey 1977, Eckman in press]).

The older age group was relatively more numerous at Sag Harbor, where the population also exhibited a wider size range. Therefore, the relation between peak gonadal weight prior to spawning, and shell height, at $5 \mathrm{~mm}$ intervals, is shown in Fig. 4 for this station. Gonadal weight increased with body size, attained a maximum at about $57 \mathrm{~mm}$ and then declined. The larger size class (60 to $65 \mathrm{~mm}$ ), was comprised entirely of 2 nd year survivors. The relation between shell height and gonad weight of 1st year scallops in May can be described by the regression equation: $\log \mathrm{G}=$ $-2.349+2.969 \log \mathrm{H}\left(\mathrm{r}^{2}=0.66 ; \mathrm{n}=74\right)$. The mean gonad weight of 2nd year scallops (mean height $=62$ 


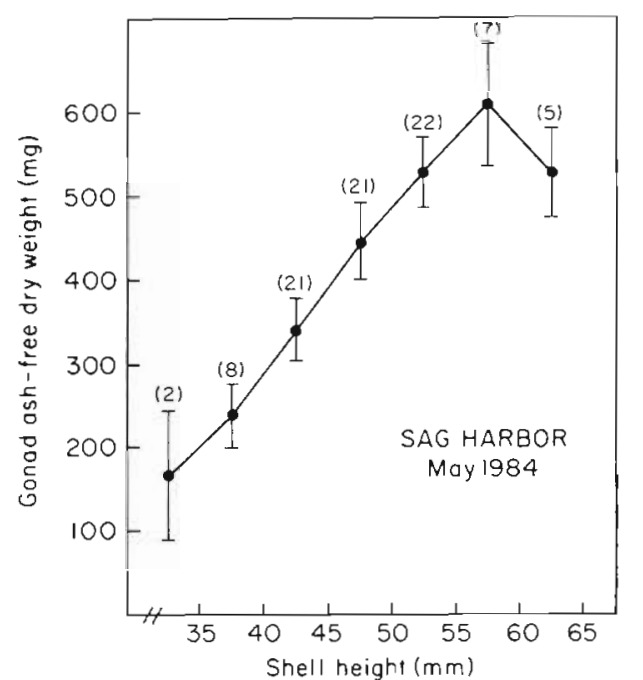

Fig. 4. Argopecten irradians. Relation between peak gonad ash-free dry weight and shell size of Sag Harbor scallops at $5 \mathrm{~mm}$ intervals (pooled samples from May 17 and 24). Scallops from both 1982 and 1983 year-classes are included. Values are means $\pm 95 \%$ confidence intervals; number of individuals indicated between brackets

$\mathrm{mm})$ at this site was thus $45 \%$ lower than that predicted on the basis of size from the above equation.
The gonad allometric condition factor prior to spawning, gonad weight (shell height) ${ }^{b}$, where $b=$ regression coefficient of the allometric equation, is shown in Table 5. This condition factor allows a relative comparison of gonad weights among individuals of different sizes (Weatherley 1972), and is normally distributed (chi-square test for goodness of fit, $p>0.025$ ). No significant difference was found between $\log \mathrm{G}$ vs $\log \mathrm{H}$ functional regression coefficients among stations ( $p>0.5$; Clarke 1980). Therefore, a mean slope of 3.3 was used in calculating the allometric factor. The allometric factor of each individual 2 nd year scallop is compared to the mean calculated for the 1st year cohort during the same sampling date (t-test for the difference between a single specimen and a sample; Sokal \& Rholf 1981). The series of independent significance tests are combined for each station (Sokal \& Rholf 1981, p. 780). This analysis confirms that at Sag Harbor the 2nd year cohort achieved a significantly lower overall size-specific reproductive output than the 1 st year cohort $(p<0.01)$. The same result is obtained for Mashomack scallops, but the difference between the 2 cohorts, although significant, is less pronounced $(p<0.05)$. In this case, 3 low probability values in the series lead to overall

Table 5. Argopecten irradians. Comparison between the gonad allometric factor $\left(\mathrm{G} / \mathrm{H}^{3}{ }^{3}\right.$ G in $\mathrm{mg}, \mathrm{H}$ in $\left.\mathrm{cm}\right)$ prior to spawning of individual 2nd year scallops (1982 cohort) and 1st year scallops (1983 cohort) (see text for explanation). p: probability level of a t-test for the difference between a single specimen and a sample; ns; non-significant; " significant at $p<0.05 ;{ }^{\prime} p<0.01$

\begin{tabular}{|c|c|c|c|c|}
\hline Site/date & Height $(\mathrm{mm})$ & $\mathrm{G} / \mathrm{H}^{3.3}$ & $\mathrm{G} / \mathrm{H}^{33}$ of 1983 cohort $\overline{\mathrm{X}}( \pm \mathrm{SD})$ & $\mathrm{p}$ \\
\hline \multicolumn{5}{|l|}{ Barcelona } \\
\hline 1 Jun & - & - & $2.480( \pm 0.472)$ & \\
\hline \multicolumn{5}{|c|}{ Three Mile Harbor } \\
\hline 1 Jun & 65.5 & 1.254 & $2.924( \pm 0.604)$ & $0.011^{\cdots}$ \\
\hline \multicolumn{5}{|l|}{ Sag Harbor } \\
\hline 17 May & 60.85 & 1.456 & $2.834( \pm 0.696)$ & $0.062 \mathrm{~ns}$ \\
\hline 17 May & 64.5 & 1.310 & & $0.042^{\circ}$ \\
\hline 25 May & 63.3 & 1.160 & $2.467( \pm 0.563)$ & $0.030^{\circ}$ \\
\hline 25 May & 61.2 & 1.216 & & $0.037^{\circ}$ \\
\hline 25 May & 59.75 & 1.401 & & $0.073 n s$ \\
\hline $25 \mathrm{May}$ & 63.85 & 1.026 & & $0.016^{*}$ \\
\hline 1 Jun & 60.35 & 1.817 & $2.494( \pm 0.711)$ & $0.361 \mathrm{~ns}$ \\
\hline \multirow[t]{2}{*}{6 Jun } & 66.65 & 0.515 & $2.509( \pm 1.009)$ & $0.070 \mathrm{~ns}$ \\
\hline & & \multicolumn{3}{|c|}{$-2 \Sigma \ln p=41.05{ }^{*} ; \mathrm{df}=16$} \\
\hline \multicolumn{5}{|l|}{ Mashomack } \\
\hline 25 May & 63.75 & 1.278 & $2.129( \pm 0.522)$ & $0.125 \mathrm{~ns}$ \\
\hline 25 May & 63.1 & 1.883 & & $0.658 \mathrm{~ns}$ \\
\hline 25 May & 62.35 & 0.644 & & $0.0097 \cdots$ \\
\hline 25 May & 65.25 & 1.733 & & $0.463 \mathrm{~ns}$ \\
\hline 25 May & 60.15 & 1.903 & & $0.685 \mathrm{~ns}$ \\
\hline $1 \mathrm{Jun}$ & 60.85 & 1.494 & $3.106( \pm 0.772)$ & $0.049^{\circ}$ \\
\hline $1 \mathrm{Jun}$ & 64.1 & 2.616 & & $0.542 \mathrm{~ns}$ \\
\hline \multirow[t]{2}{*}{$6 \mathrm{Jun}$} & 68.8 & 1.293 & $1.980( \pm 0.320)$ & $0.046^{\circ}$ \\
\hline & & \multicolumn{3}{|c|}{$-2 \Sigma \ln p=29.98^{\circ} ; \mathrm{df}=16$} \\
\hline
\end{tabular}


rejection of the null hypothesis (equal allometric factors of the 2 cohorts).

Furthermore, Barcelona and Mashomack 1st year scallops were found to differ significantly in their mean gonadal allometric factors immediately prior to spawning (ANOVA and GT2-test, $\mathrm{p}<0.01$ ).

\section{Somatic growth}

At Three Mile Harbor, the adductor muscle comprised on average between $49 \%$ (Jun) and $55 \%$ (Aug) of the scallops' total AFDW of somatic tissues. Changes in muscle weight described in this study thus represent a major component of somatic growth. The mean adductor muscle weight of scallop populations (1983 cohort) is shown in Fig. $5 \& 6$. Scallops were significantly larger in terms of shell height at Mashomack and Sag Harbor than at Barcelona and Three Mile Harbor, both prior to spawning and by late September (Table 2, ANOVA and GT2-test, $\mathrm{p}<0.05$ ). Mashomack and Barcelona populations also differed significantly (by $27 \%$ ) in their mean adductor muscle weight in the fall (ANOVA and GT2-test, p<0.01). On the other hand, mean muscle weight in late September was similar for Sag Harbor and Barcelona scallops (nonsignificant difference at $p>0.1$ ), in spite of the significant difference in mean shell height between populations at these 2 sites. This result is attributed to the lower adductor muscle condition at Sag Harbor (Table
Fig. 5. Argopecten irradians. Mean adductor muscle weight of bay scallop populations in Northwest Harbor in 1984
Fig. 6. Argopecten irradians. Mean adductor muscle weight of bay scallop pupulations in the 2 enclosed embayments in 1984. Values are also shown for Sag Harbor scallops during and after the 1985 algal bloom
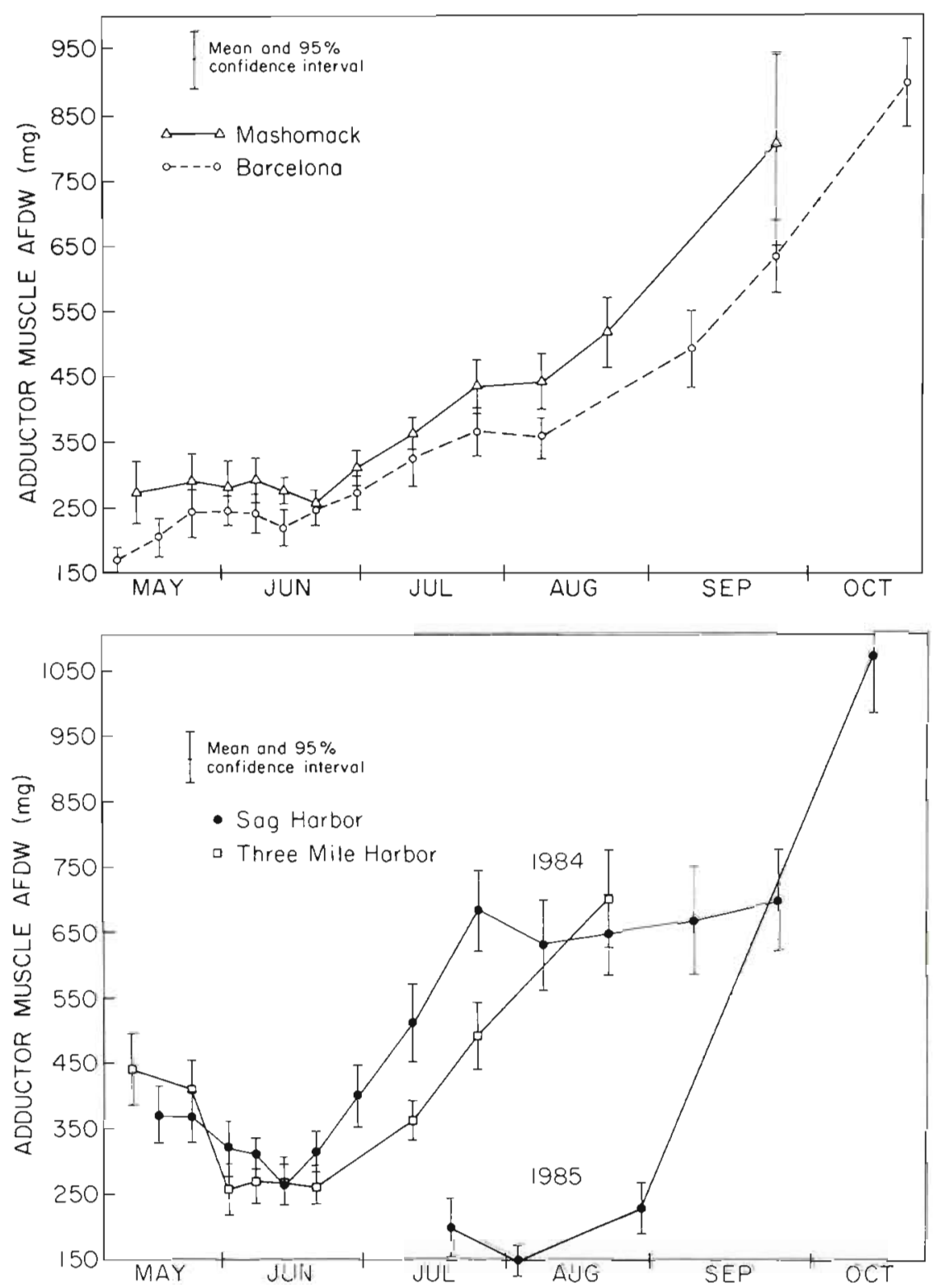
2), and suggests that food limitation may be occurring within this shallow, protected body of water. Differences in food availability rather than temperature are invoked, since similar water temperatures were measured at the 2 sites during September (Fig. 2).

Scallops experienced little change in adductor muscle condition during the main period of gonadal buildup in May, at either Barcelona or Mashomack, the 2 open water sites (Fig. 3). In contrast, in the 2 enclosed bays, muscle condition declined considerably (by $42 \%$ ) during this period, indicating that gonad growth took place at the expense of stored muscle reserves at these sites

At all sites except Barcelona, adductor muscle condition increased rapidly following initial spawning (Fig. 3). At Barcelona however, muscle condition remained fairly constant until October. These data suggest that substantial evacuation of the gonad may be necessary before somatic buildup can resume. This shift to adductor muscle growth following spawning may be under neuroendocrine control. In Mytilus edulis gametogenesis and nutrient storage are antagonistic processes controlled by secretory products from different ganglia (Lubet et al. 1978).

Shell growth nearly ceased during the reproductive period (May through Jul) and resumed during the postspawning period (Aug through Oct, the end of the sampling period in this study). The decline in standarized adductor muscle weight observed at all stations except Barcelona during August-September (Fig. 3) is interpreted here as an artifact resulting from uncoupled patterns of shell and tissue growth during this period (as illustrated by Hilbish 1986), rather than a true loss in condition. Shell and tissue growth do not occur simultaneously or at the same rate during this time. Rapid post-spawning buildup of muscle reserves is followed by a period in which shell growth proceeds at a faster rate than tissue growth.

\section{Effects of the 1985 algal bloom}

The picoplanktonic alga responsible for the 1985 summer bloom $(2.5 \mu \mathrm{m}$ in equivalent spherical diameter) remains as yet unidentified. A bloom of similar characteristics (size, cell densities and temporal and spatial scale) co-occurred in Narragansett Bay, Rhode Island, USA in 1985, and was attributed to a newly described chrysophycean, Aureococcus anorexefferens (J. Sieburth, pers. comm.). In Sag Harbor, its density peaked at 1800 cells $\mu l^{-1}$ in June, and remained at 828 cells $\mu \mathrm{l}^{-1}$ on July 19. Significant reductions in cell density followed heavy precipitation and storm events, resulting in concentrations of 650,230 and $37{\text { cells } \mu l^{-1}}^{-1}$ on August 2, August 29 and October 1 respectively.
Visual inspection of gonads indicated that Sag Harbor scallops were ripe in June, but the 1985 spawning produced no recruitment of set. By the 3rd week of July the gonad weight of a standard sized scallop was $78 \%$ lower than recorded in 1984, indicating that scallops resorbed their gametes or spawned out earlier than the previous year.

In early August mean adductor muscle weights for the Sag Harbor population were found to be significantly reduced, by $76 \%$, relative to the previous year (Fig. 6). Mean shell height $(\bar{X}=46.7 \mathrm{~mm} ; \mathrm{SD}=3.0$; $n=30$ ) was however, only $13 \%$ below that of 1984 . Following receding of the bloom, somatic growth rate increased dramatically throughout the fall. Adult survivors experienced a $9 \%$ increase in muscle AFDW per day, so that the mean weight surpassed that of populations in 1984 . The surviving population thus exhibited remarkable resilience, both in the speed and degreee of recovery, following prolonged starvation stress. Mortality rates were not documented. Results obtained for Sag Harbor scallops are representative of other areas in the Peconic estuary affected by the bloom. This was confirmed by sampling Barcelona populations on August 9: mean muscle weight was $62 \%$ lower than the previous year, and complete recruitment failure had taken place.

Recovery of scallops was accompanied in the fall (Oct 11) by the establishment of a diverse phytoplankton assemblage, dominated in terms of volume by chain-forming diatoms, with Chaetoceros species being prevalent (Bricelj unpubl. data). Only 2 diatom species were present in mid-July, while 17 species occurred in early October. Since no water samples were collected in September, it cannot be determined whether this community was present prior to the passing of hurricane Gloria through Long Island on September 27. Salinities at the Sag Harbor site throughout the 1985 study period were consistently equal to $30 \mathrm{ppt}$ and thus unusually high for the area compared to those recorded the previous year.

\section{DISCUSSION}

Scallop populations in this study exhibited secondary spawning activity throughout July and early August, following major spawning in June. An extended spawning season was also described for offshore ( $9 \mathrm{~m}$ deep) bay scallop populations in Buzzards Bay, Massachusetts, which remained competent for spawning until early September, while spawning had ceased among inshore $(2 \mathrm{~m}$ ) populations (Capuzzo \& Hampson 1984). In a study conducted in 1974 in 3 shallow Long Island bays (Three Mile Harbor, Accabonac Harbor and Montauk Lake), primary 
spawning of bay scallops was also found to occur during June, with reduced spawning activity continuing into July (Hickey 1977).

It is of considerable interest to determine the contribution of this late spawning to scallop recruitment in the Peconic estuary. A study of the influence of hydrodynamics on scallop recruitment to the bottom was conducted during 1983 and 1984 at sites off Mashomack and Barcelona Point (Eckman in press.). In 1984, recruitment of dissoconchs onto eelgrass peaked in early July and continued through July 12 within Northwest Harbor. There was no evidence of a 2nd recruitment peak in late July, suggesting that the late spawning observed in the present study did not result in significant recruitment. Settlement during August cannot be evaluated however, since sampling in Eckman's study was discontinued on August 2. Since scallops became increasingly asynchronous following the major June spawning, only a small segment of the population may be spawning in late summer. Thus gamete densities in the water column may be too low at this time to yield successful recruitment. Other factors, e. g. hydrographic conditions and food availability, could, however, account for recruitment failure at this time. Further investigation of recruitment intensity in late summer and early fall is required.

Weight loss on spawning provides a more accurate measure of reproductive output when spawning occurs over a short, discrete period of time. Since spawning in this study was fairly protracted, it is possible that additional gamete synthesis took place during the spawning period, thus resulting in slightly underestimated values of gonad output.

At Sag Harbor, where a larger sample size of older scallops was available, 2nd year scallops achieved a lower reproductive output than expected from the power curve relating gonad output to shell height in younger scallops. Similar results were obtained for the iteroparous Iceland scallop Chlamys islandica. Vahl (1984) found that in this species gonad output decreased markedly with an increase in shell height, after reaching a maximum at about 80 to $85 \mathrm{~mm}$. In contrast, gamete production in Placopecten magellanicus reaches an asymptote but does not decrease with age (MacDonald \& Thompson 1985).

The reproductive cycle of bay scallops is controlled by endogenous and exogenous factors, primarily food and temperature (Sastry 1979 and articles reviewed therein). Although food concentrations were not measured in the present study, 2 phytoplankton bloom periods have been described in the Peconic estuary. A characteristic, mid-winter diatom bloom is followed by a less well-defined chlorophyll a peak in July-August (Bruno et al. 1980) or September (Turner et al. 1983). Declining chlorophyll levels are measured in October.
Therefore, in the Peconic estuary, gonadal growth does not appear to coincide with peak phytoplankton production. In this respect, these scallop populations resemble Massachusetts populations (Sastry 1979).

\section{Site-specific differences}

Newell et al. (1982) found no discernible latitudinal trend in the timing of the reproductive cycle of Mytilus edulis on the east coast of the USA. Greatest differences were observed among 2 mussel populations at the same latitude on Long Island, New York, which experienced a similar temperature regime. These differences were attributed to local differences in food availability. Greater reproductive output and total production have been reported for $M$. edulis populations only a few km apart (Bayne \& Worrall 1980). Significant variation in reproductive output over a small geographical range was also found in Placopecten magellanicus from different depths (MacDonald \& Thompson 1985). Significant differences in growth and reproductive cycles between neighboring onshore and offshore bay scallop populations in Buzzards Bay, (2 and $9 \mathrm{~m}$ deep respectively), were reported by Capuzzo \& Hampson (1984). In the present study, greatest differences in mean shell height, gonad condition, adductor muscle weight in the fall, fecundity and timing of spawning, were observed between Mashomack and Barcelona, 2 sites found only $1.5 \mathrm{~km}$ apart, and differing by only $1.5 \mathrm{~m}$ in mean depth. Such differences among adjacent sites must be considered in describing latitudinal patterns.

The results of this study suggest that the timing of spawning may be a critical factor in determining the size of harvested scallops in their 2 nd year. Under optimum food conditions, early spawning, triggered by higher or more variable temperatures, may allow recruits to achieve a larger size and accumulate reserves before attaining their first winter. Earlier spawning and shift to somatic production rather than higher growth rates may explain the greater mean shell height of scallops at Sag Harbor compared to Barcelona. This is compensated for however, by the higher adductor muscle condition at Barcelona (Table 2) resulting in comparable mean muscle weights in the fall at the 2 sites.

Greatest reproductive output and adductor muscle mean weight and condition in this study were attained at Mashomack, a relatively shallow, high energy environment where food limitation is unlikely to occur. This site was the most favorable for growth of adult scallops, although it may not be a favorable environment for postset. Eckman (in press) found that bay scallop recruits did not persist beyond the end of July 
at the Mashomack site. He suggested that juveniles may be readily dislodyed from eelgrass blades onto the sediment during strong tidal currents occurring at this site. The Mashomack adult population sampled in our study may thus be comprised of individuals which survived this dislodgement as juveniles. Alternatively, scallops might have occupied this site at a later date by migrating across the 6 to $8 \mathrm{~m}$ deep channel separating it from adjacent scallop beds in Northwest Harbor.

Gonadal growth in bivalves is supported directly by the assimilated food ration and/or by nutrient reserves stored during periods when food is abundant (Bayne 1976, Sastry 1979). A relatively greater contribution from adductor muscle reserves in supporting reproduction has been noted in Florida and North Carolina bay scallop populations than in Massachusetts. This difference has been attributed to increased temperaturedependent metabolic demand and lower food availability with decreasing latitude. In the present study, the relative importance of the adductor muscle as the organ of reproductive energy storage is site-specific. Utilization of muscle reserves was observed in the 2 enclosed harbors, where temperatures were highest and circulation more restricted, while in Northwest Harbor, a more open site, gonadal build-up appears to rely on available food.

Cessation of adductor muscle growth in late summer in Sag Harbor is not due to the attainment of maximum size of scallops, but is probably due to the occurrence of food limitation during this period. High densities of suspension feeders can experience flow-dependent food limitation (Wildish \& Kristmanson 1984, 1985). Summer densities of up to 70 scallops $\mathrm{m}^{-2}$ have been reported in the Niantic River estuary, Connecticut, USA (Cooper \& Marshall 1963). Assuming a mean temperature of $20^{\circ} \mathrm{C}$, and a weight-normalized clearance rate of $4.851 \mathrm{~h}^{-1}$ ( $\mathrm{g}$ dry tissue weight) ${ }^{-1}$ (Palmer 1980), we can estimate that roughly 63 and $224 \%$ of the volumes of Sag Harbor and Three Mile Harbor, respectively, could be pumped through the gills of a scallop population found at a density of 2 adults $(2 \mathrm{~g}$ tissue dry weight; $57 \mathrm{~mm}$ shell height) and 2 juveniles $(0.1 \mathrm{~g} ; 26 \mathrm{~mm}) \mathrm{m}^{-2}$, during the residence time of these embayments. These estimates are based on a residence time of $10.6 \mathrm{~d}$ for Three Mile Harbor, and $2.25 \mathrm{~d}$ for Sag Harbor (calculated as the product of the bay volume and the pollution susceptibility [Weyl 1974]). Clearance rates (CR) of adult and juvenile scallops are calculated from the equation : $\mathrm{CR}=\mathrm{CR}_{\mathrm{s}} \times \mathrm{W}^{\mathrm{b}}$, where $\mathrm{b}=0.58$ (Bayne \& Newell 1983) and $\mathrm{CR}_{\mathrm{s}}$ is the clearance rate of a scallop of $1 \mathrm{~g}$ dry tissue weight. Eckman (in press) found that growth rate of postset scallops within a slow current region in Northwest Harbor in 1983 was significantly greater at a lower eelgrass density. He suggested that growth rate may be limited by the lower flux of seawater within an area of high eelgrass density. Comparable results, however, were not obtained in 1984. Thus, the influence of hydrodynamics on food availability remains to be conclusively demonstrated for these populations. Although stabilized by eelgrass, sediments at Sag Harbor exhibited a high silt-clay content (Table 1). Differences in the levels of resuspended sediments among sites and their influence on growth should also be examined in future studies.

\section{Latitudinal patterns}

Fig. 7 shows seasonal changes in the gonad index ([gonad dry weight/total tissue dry weight] $\times 100$ ) of New York bay scallop pupulations (data from this

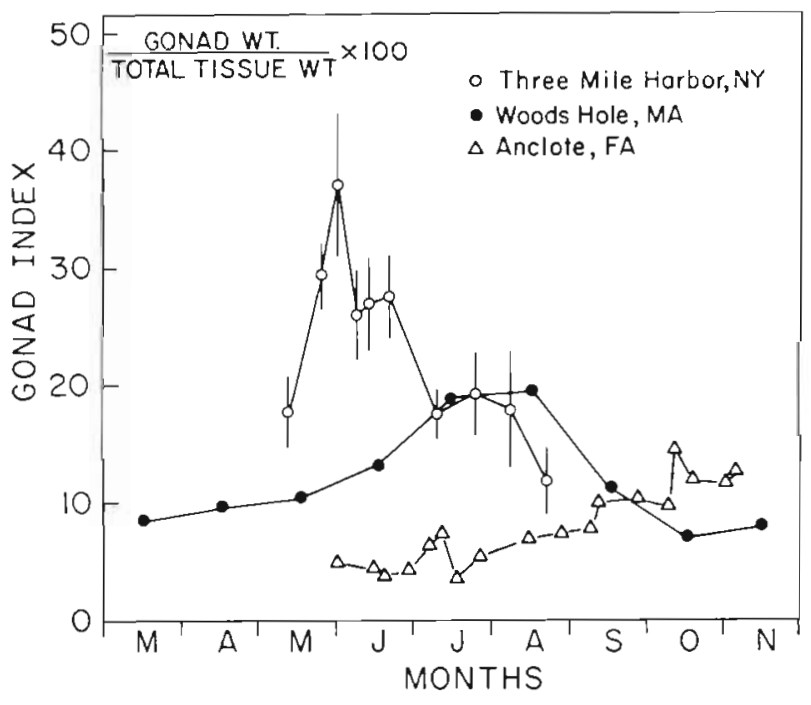

Fig. 7: Argopecten irradians. Gonad index of populations in New York (NY; present study), Massachusetts (MA; Sastry 1970) and Florida (FA; plotted from data by Barber \& Blake 1983). The index is based on dry tissue weights for NY (means $\pm \mathrm{SD}$ ) and FA scallops, and on wet weights for MA scallops

study) compared to those from Florida (Barber \& Blake 1983). Data for a Massachusetts population are also included, although they are expressed in terms of wet weight (Sastry 1970). Several important differences are revealed. Firstly, although the main spawning acitivity for Florida scallops is reported to occur in October, no discrete spawning peak, comparable to that observed at northern latitudes, is apparent. This suggests that 'dribble-spawning' is occurring at the southernmost latitude. These observations support the generalization that a northern hemisphere temperate species generally has a more extended spawning period in the southern part of its range than in more northern latitudes (Rand 1973). A decreasing mean oocyte diameter, as determined from histological sections, has 
been reported for Argopecten irradians along a latitudinal gradient from Massachusetts to Florida (Barber \& Blake 1983). A smaller mean oocyte size from histological analysis, however, does not necessarily reflect spawning of smaller, and presumably less viable, oocytes. This finding may simply reflect a greater asynchrony in the development stage of oocytes within gonadal follicles in the Florida population. Latitudinal differences in egg size are best determined from sizefrequency distributions of ripe, unfertilized oocytes after they are released from the gonad.

Secondly, the gonad index of New York scallops is about 3 times that of bay scallops at their southern distributional limit. The mean gonad index attains $37 \%$ in Three Mile Harbor, but only $14 \%$ in Florida. Therefore, bay scallop populations from New York and Florida vary not only in the time of the year when successive events in the reproductive cycle take place, but also in the amplitude of the cycle. Using data from Barber \& Blake (1983) we can calculate that Florida scallops (mean height $=60 \mathrm{~mm}$ ) experienced a gonadal weight loss equal to $110 \mathrm{mg}$ during fall spawning. In the present study, the gonad weight loss of a $60 \mathrm{~mm}$ scallop over the spawning season (estimated from regression equations in Table 3) ranges from 717 to $849 \mathrm{mg}$. Thus, the size-specific reproductive output of New York scallops is about 7 times greater than that of Florida scallops. Thirdly, Fig. 7 illustrates the importance of frequent sampling, at weekly intervals, in order to determine peak gonadal weights and spawning events in this rapidly growing species. The Woods Hole population was sampled at monthly intervals (Sastry 1970), and it is possible that a higher index was attained during July-August. A maximal gonad index (based on wet weights) of ca $38 \%$ was reported for inshore (2 $\mathrm{m}$ deep) populations in Buzzards Bay, Massachusetts (Capuzzo \& Hampson 1984).

\section{Interspecies comparisons}

Reproductive effort, the proportion of net production devoted to reproduction, is generally higher in semelparous molluscs than in iteroparous molluscs that breed more than once in their lifetime (Browne \& Russell-Hunter 1978). Because reproductive effort is age-dependent, interspecies comparisons have been attempted for organisms of the same age (Barber \& Blake 1986), or equivalent ages expressed as a proportion of the expected life span (MacDonald 1984).

The ratio of gonad to parental somatic weight has frequently been used as an index of reproductive effort, although measurements obtained using energy budgets have been regarded as preferable (Hirshfield \& Tinkle 1975). In a comparison of limpet species, however, Parry (1982) found that estimates of reproductive effort based on maximum lifetime gonad to body weight ratios yielded similar results to those based on energy budgets. Annual gonad output as a percentage of somatic tissue weight of Argopecten irradians, a semelparous hermaphrodite, is compared to that of 3 iteroparous pectinids in Table 6. Reproductive output is calculated from gonadal weight loss on spawning. In order to allow for differences in longevity and growth trajectories among species, values in Table 6 are calculated for that age/size class at which reproductive output is maximized, and thus represent maximum values attained over each species' life span. $A$. irradians exhibits an annual gonad output to somatic

Table 6. Annual reproductive output as a percentage of somatic dry tissue weight before spawning of Argopecten irradians compared to that of other pectinids (maximum values attained over the species lifespan)

\begin{tabular}{|c|c|c|}
\hline \multirow[t]{2}{*}{ Species } & Gonad output $(\mathrm{dry} w \mathrm{w}) \times 100$ & Source of data \\
\hline & \multicolumn{2}{|l|}{ Dry wt somatic tissues } \\
\hline $\begin{array}{l}\text { Argopecten irradians (bay scallop), Three Mile Harbor, } \\
\text { New York, USA }\end{array}$ & 61.2 & Present study \\
\hline Chlamys islandica (Iceland scallop), Norway & $16.5^{\mathrm{d}}$ & Vahl 1984 \\
\hline Chlamys varia (black scallop), France & $8.1-17.3^{b}$ & Schafee \& Lucas 1980 \\
\hline $\begin{array}{l}\text { Placopecten magellanicus (giant scallop), Newfoundlan } \\
\text { Canada } \\
\qquad \begin{array}{l}\text { Sunnyside } \\
\text { Dildo } \\
\text { Terra Nova }\end{array}\end{array}$ & $\begin{array}{l}34.2^{\mathrm{c}} \\
19.2 \\
18.6\end{array}$ & $\begin{array}{l}\text { MacDonald 1984, } \\
\text { MacDonald \& Thompson } 1985\end{array}$ \\
\hline \multicolumn{3}{|c|}{$\begin{array}{l}{ }^{\mathrm{b}} \text { Gonad output includes that of } 2 \text { annual spawning peaks; calculated for scallops } 50.7 \mathrm{~mm} \text { shell height } \\
{ }^{\mathrm{c}} 2 \text { to } 3 \mathrm{yr} \text { mean estimated for } 18 \mathrm{yr} \text { old scallops, } 170 \mathrm{~mm} \text { shell height, using regression parameters from Tables A-18, } 19,24 \\
25,26,27 \text { (MacDonald } 1984 \text { ) }\end{array}$} \\
\hline
\end{tabular}


tissue ratio 2 to 8 times greater than the iteroparous scallop species.

\section{Somatic growth}

Adductor muscle growth of commercially harvested beds in Northwest Harbor continued beyond the opening of the harvesting season in mid-September (Fig. 5). Natural mortality estimates during the fall are necessary in order to evaluate the net gain in biomass which might result from a delay in harvesting. Mass senescent mortality does not occur in these populations until midwinter (Bricelj unpubl.). Cumulative mortality of scallops of the 1984 cohort held in cages was less than $9 \%$ between September and November. Furthermore, bay scallops in similar habitats in Connecticut appear to achieve partial size refuge from predation at ca $40 \mathrm{~mm}$ in shell height and experience low predation intensity beyond this size (Tettelbach 1986). Natural mortality of post-spawning individuals is thus not expected to be significant during the fall, suggesting that a delay of 1 or 2 mo in harvesting could significantly increase the meat yield of scallops in this area. Year-to-year variations in growth rates and sitespecific differences should however, be taken into consideration in management of this fishery. A delay in the harvesting season, based on similar considerations, has also been recommended for the scallop fishery in North Carolina (Kellogg \& Spitsbergen 1983) and Massachusetts (Hampson \& Capuzzo 1984).

Acknowledgements. Thanks are due to Raoul Castaneda for his valuable assistance in field sampling, Tom Ball for providing us with boat docking area, Gregg Rivara and Jane Lu for help in data analysis, and Jim Eckman, Mario Vieira and Bob Cerrato for their helpful advice. This study was supported by a grant from New York Sea Grant Institute, Department of Commerce.

\section{LITERATURE CITED}

Barber, B. J., Blake, N. J. (1981). Energy storage and utilization in relation to gametogenesis in Argopecten irradians concentricus (Say). J. exp. mar. Biol. Ecol. 52: 121-134

Barber, B. J., Blake, N. J. (1983). Growth and reproduction of the bay scallop, Argopecten irradians (Lamarck) at its southern distributional limit. J. exp. mar. Biol. Ecol. 66: $247-256$

Barber, B. J., Blake, N. J. (1986). Reproductive effort and cost in the bay scallop. Argopecten irradians concentricus. Int. J. Invert. Repr. Dev. 10:51-57

Bayne, B. L. (1976). Aspects of reproduction in bivalve molluscs. In: Wiley, M. L. (ed.) Estuarine processes. Academic Press, New York, p. 432-448

Bayne, B. L., Newell, R. C. (1983). Physiological energetics of marine molluscs. In: Saleuddin, A. S. M., Wilbur, K. M. (ed.) The Mollusca, Vol. 4. Academic Press, New York, p. $407-515$
Bayne, B. L., Worrall, C. M. (1980). Growth and production of mussels Mytilus edulis from two populations. Mar Ecol. Prog. Ser, 3: 317-328

Bayne, B. L., Salkeld, P. N., Worrall, C. M. (1983). Reproductive effort and value in different populations of the marine mussel, Mytilus edulis L. Oecologia (Berl.) 59: 18-26

Belding, D. L. (1931). The scallop fisher of Massachusetts Comm. Mass. Dept. Conserv. Div. Fish and Game, Mar. Fish. Ser. 3, Boston

Browne, R. A., Russell-Hunter, W. D. (1978). Reproductive effort in molluscs. Oecologia (Berl.) 37: 23-27

Bruno, S. F., Staker, R. D., Sharma, G. M. (1980). Dynamics of phytoplankton productivity in the Peconic Bay estuary, Long Island. Estuar coast. mar. Sci. 10: 247-263

Capuzzo, J. M., Hampson, G. R. (1984). Comparative reproductive and developmental strategies of populations of the bay scallop Argopecten irradians irradians (Lamarck) in shallow and deep water embayments. In: Gately, E. M. (ed.) 1982/83 WHOI Annual Sea Grant Rept., p. 8-9

Clarke, A. H., Jr. (1965). The scallop superspecies Aequipecten irradians (Lamarck). Malacologia 2 (2): 161-188

Clarke, M. R. B. (1980). The reduced major axis of a bivariate sample. Biometrika 67 (2): 441-446

Cooper, R. A., Marshall, N. (1963). Condition of the bay scallop, Aequipecten irradians, in relation to age and the environment. Chesapeake Sci. (4): 126-134

Eckman, J. E. (1986). The role of eelgrass hydrodynamics in recruitment, growth and survival of Argopecten irradians (L.) and Anomia simplex (D'Orbigny). J. exp. mar. Biol. Ecol. (in press)

Gutsell, J. S. (1930). Natural history of the bay scallop. U.S. Bur. Fish. Bull. 46: 569-632

Hardy, C. D. (1976). A preliminary description of the Peconic Bay esturay. Mar. Sci. Res. Center, State Univ. of New York at Stony Brook, Special Report 3, p. 1-65

Hickey, M. T. (1977). Age, growth, reproduction and distribution of the bay scallop. Aequipecten irradians irradians (Lamarck), in three embayments in eastern Long Island, New York, as related to the fishery. MS thesis, CW Post College, Long Island University, New York

Hilbish, T. J. (1986). Growth trajectories of shell and soft tissue in bivalves: seasonal variation in Mytilus edulis. J. exp. mar. Biol. Ecol. 96: 103-113

Hirshfield, M. F., Tinkle, D. W. (1975). Natural selection and the evolution of reproductive effort. Proc. natn. Acad. Sci U.S.A 72: 2227-2231

Kellogg, R. L., Spitsbergen, D. (1983). Predictive growth model for the meat weight (adductor muscle) of bay scallops in North Carolina. Univ. of North Carolina, Sea Grant College Publ. No. 6

Kruczynski, W. L. (1972). The effect of the pea crab, Pinnotheres maculatus Say, on growth of the bay scallop Argopecten irradians concentricus (Say). Chesapeake Sci. 13: $218-220$

Lubet, P., Herlin, P., Mathieu, M., Collin, F. (1978). Tissu de réserve et cycle sexuel chez les lamellibranches. Haliotis 7: 59-62

MacDonald, B. A. (1984). The partitioning of energy between growth and reproduction in the giant scallop, Placopecten magellanicus (Gmelin). Ph. D. thesis, Memorial University of Newfoundland

MacDonald, B. A., Thompson, R. J. (1985). Influence of temperature and food availability on the ecological energetics of the giant scallop Placopecten magellanicus. II. Reproductive output and total production. Mar. Ecol. Prog. Ser 25: 295-303

Mori, K., Sato, W., Nomura, T., Imajima, M. (1985). Infestation 
of the Japanese scallop Patinopecten yessoensis by the boring polychaetes, Polydora, on the Okhotsk Sea coast of Hokkaido, especially in Abashiri waters. Bull. Jap. Soc. scient. Fish. 51 (3): 371-380

Newell, R. I. E., Hilbish, T. J., Koehn, R. K., Newell, C. J. (1982). Temporal variation in the reproductive cycle of Mytilus edulis L. (Bivalvia, Mytilidae) from localities on the east of the United States. Biol. Bull mar. biol. Lab., Woods Hole 162: 299-310

Palmer, R. E. (1980). Behavioral and rhythmic aspects of filtration in the bay scallop. Argopecten irradians concentricus and the oyster, Crassostrea virginica. J. exp. mar. Biol. Ecol. 45: 273-295

Parry, G. D. (1982). Reproductive effort in four species of intertidal limpets. Mar. Biol. 67: 267-282

Rand, W. M. (1973). A stochastic model of the temporal aspect of breeding strategies. J. theor. Biol. 40:337-351

Ricker, W. E. (1973). Linear regressions in fishery research. J. Fish. Res. Bd Can. 30; 409-434

Sastry, A. N. (1966). Temperature effects in reproduction of the bay scallops Aequipecten irradians Lamarck. Biol. Bull. mar. biol. Lab., Woods Hole 130: 118-134

Sastry, A. N. (1970). Reproductive physiological variation in latitudinally separated populations of the bay scallop, Aequipecten irradians Lamarck. Biol. Bull. mar. biol. Lab., Woods Hole 138 (1): 56-65

Sastry, A. N. (1979). Pelecypoda (excluding Ostreidae). In: Giese, A. C., Pearse, J. S. (ed.) Reproduction of marine invertebrates. Academic Press, New York, p. 113-292

Schafee, M. S., Lucas, A. (1980). Quantitative studies on the reproduction of black scallop. Chlamys varia (L.) from Lanveoc, Bay of Brest. J. exp. mar. Biol. Ecol. 42: 171-186

Sokal, R. R., Rohlf, F. J. (1981). Biometry. The principles and practice of statistics in biological research. W. H. Freeman and Co., San Francisco
Taylor, R. E., Capuzzo, J. M. (1983). The reproductive cycle of the bay scallop, Argopecten irradians irradians (Lamarck), in a small coastal embayment on Cape Cod, Massachusetts. Estuaries 6 (4): 431--435

Tettelbach, S. T. (1986). Dynamics of crustacean predation on the northern bay scallop. Argopecten irradians irradians. $\mathrm{Ph}$. D thesis, University of Connecticut

Thompson, R. J. (1984). Production, reproductive effort, reproductive value and reproductive cost in a population of the blue mussel Mytilus edulis from a subarctic environment. Mar. Ecol. Prog. Ser. 16: 249-257

Turner, H. J., Hanks, J. E. (1959). Infestation of Pecten irradians by Polydora. Nautilus 72 (4): 109-111

Turner, J. T., Bruno, S. F., Larson, R. J., Staker, R. D., Sharma, G. M. (1983). Seasonality of plankton assemblages in a temperate estuary. P. S. Z. N. I. Mar. Ecol. 4 (1): 81-99

Vahl, O. (1984). Size-specific reproductive effort in Chlamys islandica: reproductive senility or stabilizing selection? In: Gibbs, P. E. (ed.) Proc. 19th European Mar. Biol. Symp. Cambridge University Press, Cambridge, p. 521-527

Weatherley, A. H. (1972). Growth processes in fish. In: Growth and ecology of fish populations. Academic Press, New York, p. 75-80

Weyl, P. K. (1974). The pollution susceptibility of the marine waters of Nassau and Suffolk Counties, New York. Mar. Sci. Res. Center, State Univ. of New York at Stony Brook, Techn. Rep. No. 20, p. 1-21

Wildish, D. J., Kristmanson, D. D. (1984). Importance to mussels of the benthic boundary layer. Can. J. Fish. Aquat. Sci. 41: 1618-1625

Wildish, D. J., Kristmanson, D. D. (1985). Control of suspension feeding bivalve production by current speed. Helgoländer Meeresunters. 39: 237-243

Williams, G. C. (1966). Adaptation and natural selection. Princeton University Press, Princeton, New Jersey

This article was presented by Dr. B. L. Bayne; it was accepted for printing on December 18, 1986 